УДК 598.2:591.552 (571.65)

\title{
РЕЗУЛЬТАТЫ ОБСЛЕДОВАНИЯ КОЛОНИЙ МОРСКИХ ПТИЦ ВОСТОЧНОЙ ЧАСТИ ТАУЙСКОЙ ГУБЫ (Охотское море)
}

\author{
Зеленская Л. А. \\ ФГБУН Институт биологических проблем Севера ДВО РАН, г. Магадан \\ E-mail: larusrissa@gmail.com
}

\begin{abstract}
Приведены результаты учетных работ на побережье восточной части Тауйской губы, п-ове Кони и о. Завьялова и оценены изменения, произошедшие в гнездовых колониях морских птиц за последние 10-15 лет. Суммарно по последним учетам здесь гнездится более 92 тыс. морских птиц. На территории и в охранной зоне заповедника «Магаданский» на п-ове Кони наблюдается постепенное уменьшение числа колоний на западном побережье. Основная масса гнездящихся в заповедных границах морских птиц сосредоточена в районе м. Блиган - 11.1 тыс. особей и на м. Скалистый -7.5 тыс. особей. На м. Скалистый снова восстановилась колония кайр после почти 30-летнего отсутствия и их численность быстро растет. Самая крупная гнездовая колония в исследованном районе - о. Умара (более 60.2 тыс. особей) относительно стабильна по численности. Общая численность гнездящихся морских птиц на всем обследованном материковом побережье снизилась с 41.7 тыс. особей в 2009 г. до 30.2 тыс. особей в 2019 г.
\end{abstract}

Ключевые слова: колонии морских птиц, Охотское море, п-ов Кони, Тауйская губа, о. Завьялова, численность морских птиц, размещение колоний.

DOI: $10.34078 / 1814-0998-2021-108-122$

\section{ВВЕДЕНИЕ}

История изучения морских птиц Охотского моря насчитывает более 200 лет. Однако на п-ове Кони распределение колоний и численность морских птиц впервые были описаны лишь в 1987 г. в границах заповедника «Магаданский» (Лейто, Мянд, 1991). До этого существовали данные единственного учета А. Г. Велижанина на м. Скалистый, сделанные в 1974 г. (Велижанин, 1978). Тогда же он впервые описал колонию морских птиц на о. Умара (Велижанин, 1977). В 1987 г. с 26 по 29 июля эстонская молодежная комплексная экспедиция работала на о. Умара. Тогда впервые было приведено описание размещения морских птиц на острове (Лейто, Мянд, 1991). С 1991 по 1996 г. ИБПС ДВО РАН организовывал около о. Умара полевую базу. Орнитологи проводили на острове регулярные наблюдения и учеты численности птиц (Зеленская, 1995; Голубова, Плещенко, 1997). Следующие учеты мы провели здесь в 2005 г. (Зеленская, 2006), в 2006 г. (Зеленская, 2013) и в 2016 г.

Восточное побережье Тауйской губы впервые было обследовано Е. Ю. Голубовой в 1992 г. Повторные учеты колоний были проведены ею в 1996 г. (Голубова, Плещенко, 1997). В рамках мониторинга колоний морских птиц в заповеднике «Магаданский», учеты на п-ове Кони были повторены нами в 2005 г. (Зеленская, 2013), а затем дополнены в 2006 г. учетами на крупнейших колониях топорков в районе м. Блиган.

(C) Зеленская Л. А., 2021
В 2009 г. нами были проведены учеты на этом участке побережья с картированием колоний с помощью GPS-навигатора (Там же). В 2016 г. изза погодных условий были учтены птицы только в колониях на северном побережье полуострова. В 2019 г. удалось завершить инвентаризацию колоний и картирование с GPS на остальном побережье заповедной территории полуострова, что дает возможность точно отследить изменения в состоянии конкретных колоний, появление новых и исчезновение отдельных ранее известных колоний.

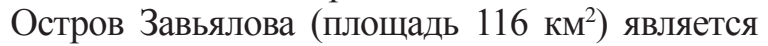
самым крупным из островов Тауйской губы. Несмотря на близость острова к г. Магадану, он долгое время был «белым пятном» в плане биологической изученности. История его изучения и освоения людьми подробно описаны (Хорева, 2003; Остров..., 2012). Инвентаризация колоний морских птиц и их картирование с GPS были проведены нами в 2009 г. и повторены через 10 лет в 2019 г.

Местоположения крупных колоний морских птиц, как правило, достаточно консервативны. Для выявления динамики изменений состояния колоний морских птиц, которые в свою очередь отражают изменения, происходящие в прибрежных акваториях, очень важен каждый учет, особенно если местоположения колоний точно фиксированы. Именно выявление изменений, произошедших за последние 10-15 лет в распределении колоний морских птиц, численности птиц в них, а также попытка объяснения этих явлений являются целью нашей работы. 


\section{МАТЕРИАЛ И МЕТОДЫ}

Район исследования. Обследование берегов и учеты морских птиц охватывали восточную часть Тауйской губы: побережье п-ова Кони, входящее в охранную зону заповедника «Магаданский», побережья зал. Одян и Речной до входа в Ольскую лагуну, а также о. Завьялова, отстоящего от п-ова Кони на 18 км (рис. 1).

Береговая полоса почти на всем протяжении п-ова Кони до м. Плоский (рис. 2, № 1) и от м. Кир до м. Беринга (рис. 3) представляет собой крутые обрывы и высокие, почти вертикальные скалистые мысы, перемежающиеся узкими долинами в местах впадения мелких рек и ручьев. Очень похоже выглядят берега о. Завьялова (рис. 4), особенно его юго-восточная сторона. Физико-географические условия, растительный и животный мир этого крупнейшего острова Тауйской губы были подробно описаны в коллективной монографии (Остров..., 2012).

Залив Речной глубоководен и мало изрезан. Залив Одян относительно узкий, заканчивается бух. Мелководная, которая точно оправдывает свое название. Северное побережье зал. Одян сильно изрезано заливчиками при впадении каждого ручья, а берега облесенные. Скалы, где имели бы возможность гнездиться морские птицы, расположены здесь в основном на мысах. Южное побережье зал. Одян и бух. Мелководная имеют низинные пологие берега и здесь нет никаких гнездовий морских птиц.
Единственный остров у восточного побережья Тауйской губы - Умара - высотой 92 м и пло-

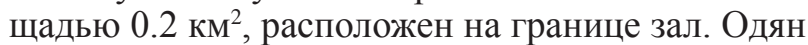
(см. рис. 2, 3). Физико-географические характеристики и растительный покров острова были подробно описаны по результатам ряда экспедиций (Голубова, Плещенко, 1997; Зеленская, 2006; Мочалова и др., 2006).

Прибрежные скальные останцы-кекуры с практически вертикальными стенами и плоской вершиной, недоступные для наземных хищников, на всем протяжении обследованного побережья встречены единично: два безымянных в районе м. Блиган (см. рис. 2) и один в зал. Одян Камень-Мугдыкын (см. рис. 3).

В работе, впервые подробно описывающей распределение колоний морских птиц в Тауйской губе (Голубова, Плещенко, 1997), показано, что оно здесь и на побережье п-ова Кони, как ее восточной границы, согласуется с зонами высокой биологической продуктивности морских вод. Биологическое разнообразие и высокая продуктивность акватории Тауйской губы обусловлены гидрологическим режимом этой акватории. На рис. 1 показана циркуляция вод в Тауйской губе в летний период (по: Чернявский, Радченко, 1994). Толщина стрелок, показывающих направление основных течений, отражает силу течения. Достаточно подробное описание и анализ этой морской экосистемы, касательно колоний морских птиц, изложены в работах А. В. Андреева $(2002,2004)$.

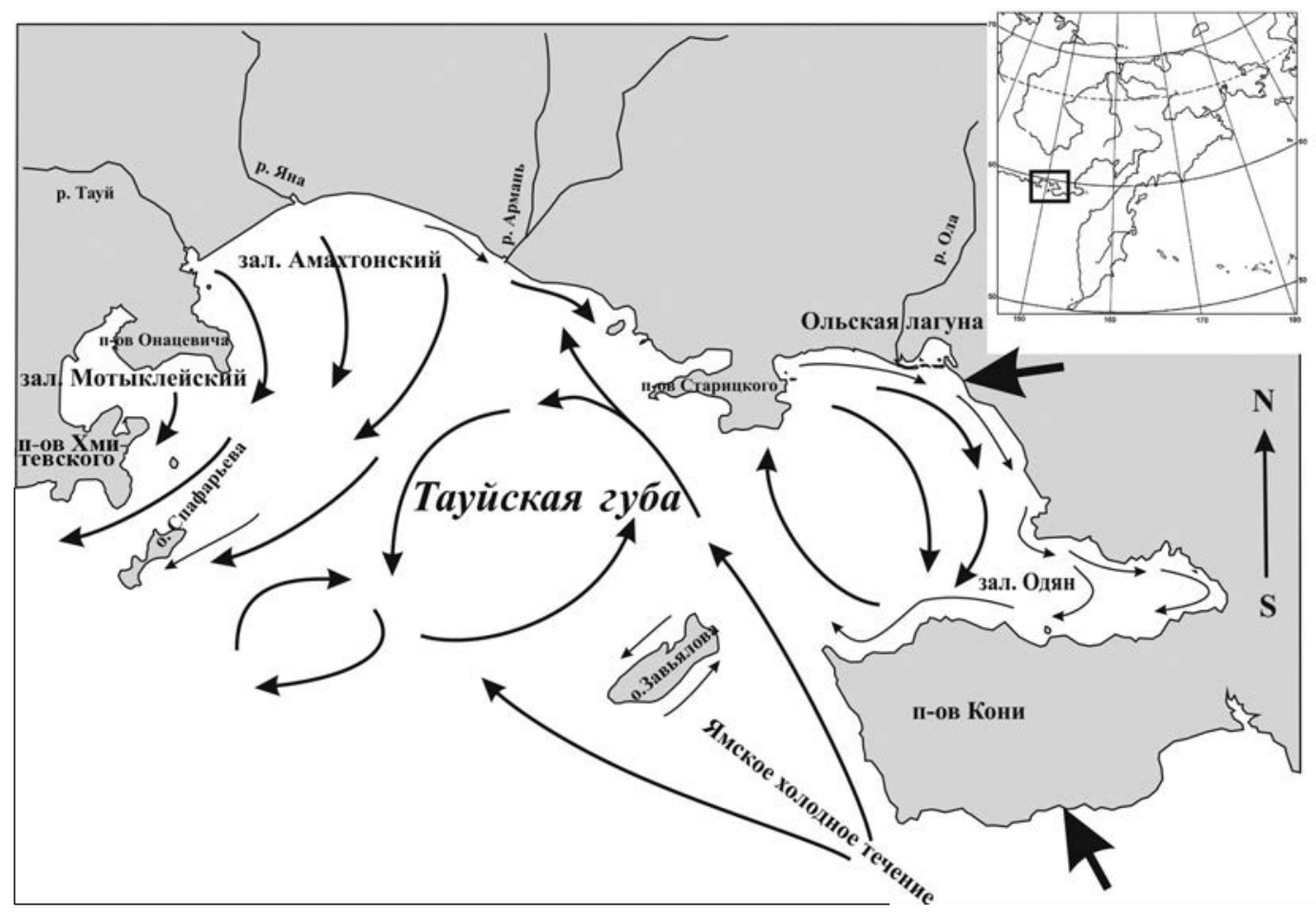

Puc. 1. Район исследования. Стрелками показана циркуляция вод в Тауйской губе в летний период (по: Чернявский, Радченко, 1994). Толстыми стрелками обозначены границы обследованного побережья

Fig. 1. Research area. Arrows show water circulation in the Tauysk Bay in the summer (after Chernyavsky, Radchenko, 1994). Thick arrows point at boundaries of the researched coast 


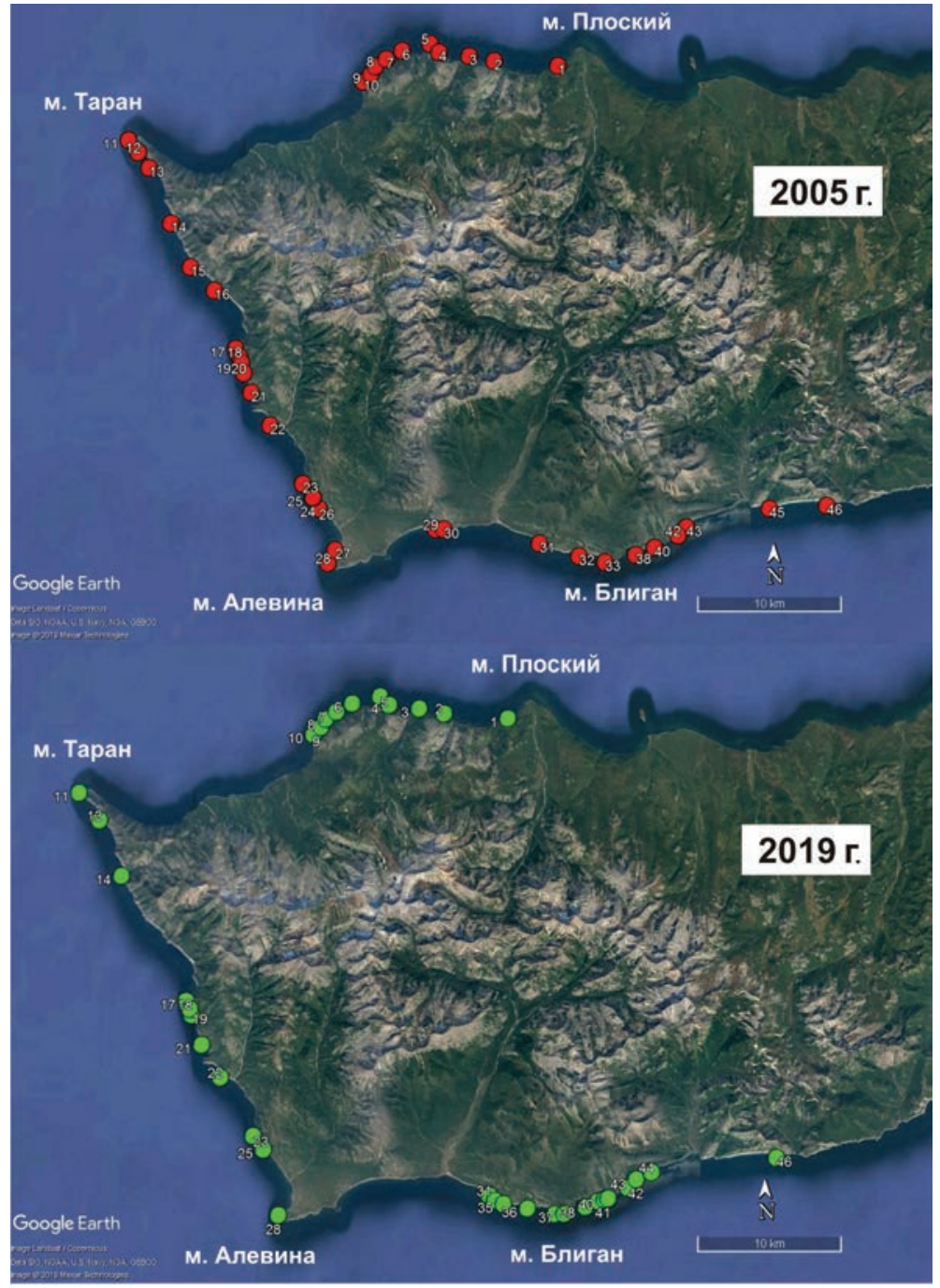

Рuc. 2. Распределение колоний морских птиц вдоль побережья п-ова Кони в разные годы

Fig. 2. Distribution of seabird colonies along the coast of the Koni Peninsula in different years

Антропогенная нагрузка на исследуемый участок побережья различная. На всем протяжении побережья п-ова Кони присутствие групп людей есть только на кордоне заповедника (м. Плоский) и в маячных хозяйствах на м. Таран и м. Алевина (см. рис. 2). В акватории не проводится рыбалка, нет туризма, и трассы каботажного флота проходят в отдалении от берегов. На о. Завьялова нет постоянных поселений людей. В последние годы в связи с интродукцией овцебыков на остров здесь построен полевой лагерь наблюдателей. Побережье на участке от м. Кир до о. Умара включительно испытывает стихийную рекреационную нагрузку (рыбаки и туристы).

Наземные хищники, ограничивающие возможности для размещения гнезд морских птиц неприступными участками скал, представлены такими видами, как лисица (Vilpes vilpes), горностай (Mustela erminra), бурый медведь (Ursus arctos) и домашние собаки. Из «воздушных хищников» наиболее серьезное значение для морских птиц имеют белоплечий орлан (Haliaeetus pelagicus), сапсан (Falco peregrinus) и ворон (Corvus corax).

Краткое описание колоний морских птиц на участках побережья уже приводились (Голубова, Плещенко, 1997), мы будем касаться этого вопроса только в плане возникших изменений в расположении колоний.

Сроки и объекты учетов. Учеты на о. Завьялова проводили 7 июля 2019 г. На п-ове Кони учеты проводили в два этапа: в 2016 г. от м. Плоский (см. рис. 2, № 1) до м. Таран (см. рис. 2, № 11) включительно и на о. Умара. В 2019 г. было продолжено обследование побережья от м. Таран до рр. Правая и Левая Клешня (см. рис. 2, № 46). Сроки проведения учетов: в 2016 г.: о. Умаpa - 19 июня, побережье п-ова Кони - 20 июня, в 2019 г. - 24 июля. Учеты птиц на побережье зал. Одян и Речной сделаны 25-26.07.2019 г.

Были картированы (взяты координаты GPS) все гнездовья морских птиц. В колониях на данном участке побережья были отмечены на гнездовье следующие виды морских птиц (в порядке уменьшения числа колоний): тихоокеанская чайка (Larus schistisagus), берингов баклан (Phalacrocorax pelagicus), очковый чистик (Cepphus carbo), топорок (Lunda cirrhata), ипатка (Fratercula corniculata), моевка (Rissa tridactyla), оба вида кайр (Uria aalge и Uria lomvia), белобрюшка (Cyclorrhynchus psittacula). Видовые названия птиц приводятся по аннотированному каталогу (Нечаев, Гамова, 2009).

Meтоды учета птиц. Все учеты начинались с раннего утра. Основная часть учетных работ проведена с борта моторной лодки, «однократным проходом» в ясную погоду, при хорошей видимости и отсутствии волнения на море, в течение светового дня, при помощи 8-кратного бинокля. Методы и способы подсчета птиц были стандартными.

Берингов баклан и моевка. Учитывали количество занятых гнезд, так как эти виды птиц не оставляют гнездо без присмотра. Птиц на воде и в «клубах» не считали, поскольку задачей было учесть именно гнездящуюся часть популяций, а в группах отдыхающих и кормящихся птиц велика вероятность концентрации неразмножающихся и, судя по оперению, неполовозрелых особей. Количество учтенных занятых гнезд удваивали (учитывая партнера), получая численность особей в колонии. 
Тихоокеанская чайка. Птиц на «клубах» и на воде не учитывали. Число птиц, обнаруженных на гнездовьях, умножали на коэффициент 0.75. Данный коэффициент мы получили методом, опробованным на Командорских островах в 2007 г.: на различных (по характеру растительного покрова, рельефу, уклону и проч.) модельных площадках два учетчика, независимо друг от друга, в пешем маршруте методично просчитывали все гнезда серокрылых чаек (Larus glaucescens). Затем те же площадки с гнездами, также два учетчика, независимо, просматривали в бинокль (не тревожа колонию) и просчитывали всех находящихся там птиц. Число гнезд при учетах «проходом» считали «истинным». Число птиц, учтенных в бинокль без беспокойства, как правило, не соответствовало количеству гнезд, так как рядом с гнездом могут находиться как оба партнера, так и один партнер. По нашим расчетам, оптимальным для получения «истинного» результата был коэффициент 0.75. Этот способ расчета был проверен на очень близком по поведению в гнездовой период виде - тихоокеанской чайке на колониях о. Шеликан и островных барах Ольской лагуны. Коэффициент «хорошо работал». Полученное число гнезд удваивали, получая число гнездящихся особей.

Очковый чистик. На о. Умара мы проводили отдельный учет очковых чистиков, который выполнялся вдоль периметра острова с борта моторной лодки. Птиц считали как на воде, так и на прибрежных камнях в период их наибольшей активности (раннее утро, штиль). Метод учета очковых чистиков основывался на нашем опыте полевых работ на о. Умара в 1995 г. Тогда методичные обследования береговых каменных развалов и сплошной учет и маркировка всех гнезд очковых чистиков проводились регулярно в течение почти 2 мес. Как правило, по учетам чистиков на воде около берегов ранним утром в период инкубации их численность почти равнялась числу обнаруженных гнезд. При этом полагали, что второй партнер находится в гнезде. Поэтому при учетах «проходом» вдоль побережья в период инкубации число всех зафиксированных на воде и берегу чистиков умножали на два, получая число гнездящихся особей.

Кайры. Оба вида кайр, как правило, не оставляют гнездо без присмотра, их учитывали только на гнездовых карнизах методом фотоучетов. В учеты попадали все кайры, так как карнизы

везде были узкими. В обеих колониях, где были обнаружены кайры, отмечено подавляющее преобладание тонкоклювой кайры, что вообще характерно для нашего региона (Голубова, 2014). Однако мы не всегда имели возможность точно идентифицировать вид кайры на фото, поэтому оба вида кайр представлены в таблицах совместно. Численность кайр в таблицах приведена без поправочного коэффициента.

Топорок. Число топорков, отмеченных на берегу и на воде около колонии, умножалось на 5 , так как полевые работы (методичные проверки всех обнаруженных нор на заселенность на модельных площадках), проведенные на о. Топорков (Командоры), показали, что обычно только около одной из трех-четырех занятых гнездовых нор мы можем видеть птицу, и нужно учесть и второго партнера. Наш почти 30 -летний опыт работ на различных островах-колониях и в акватории Охотского моря и на Командорских островах 


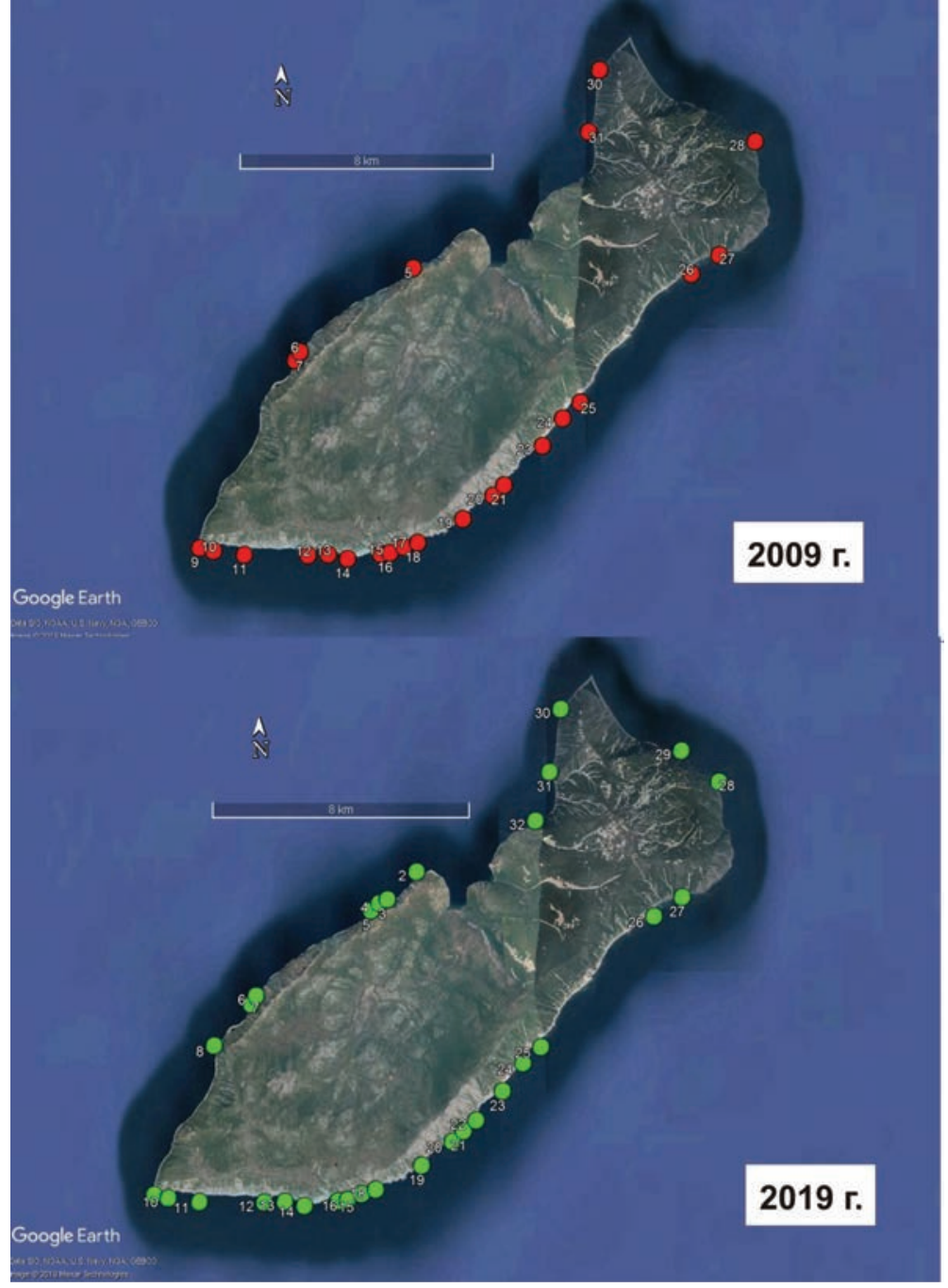

Рuc. 4. Распределение колоний морских птиц вдоль побережья о. Завьялова

Fig. 4. Distribution of seabirds colonies along the coast of the Zavyalov Island

не дает основания полагать, что есть существенные различия в стереотипах гнездового поведения топорков в разных колониях.

Ипатка. Ипаток просчитывали как на берегу, так и на воде, поскольку у берегов держатся гнездящиеся особи. Их число удваивали, учитывая гнездового партнера.

Методика фотоучетов. Этот метод был применен в колониях с очень высокой численностью открыто гнездящихся птиц. В 2016 г. на м. Скалистый и на о. Умара. В 2019 г. - на о. Камень-Мугдыкын, а также на м. Харбиз и Кир. Цифровым зеркальным фотоаппаратом были подробно отсняты скалы и обрывы, далее снимки были обработаны в программе Photoshop. Участки скальных склонов на мониторе оконтуривали и состыковывали во избежание повторных учетов тех же птиц или пропусков поверхности склона. Затем птиц просчитывали, маркируя каждую особь (кайры, чайки) или гнездо (моевки и бакланы) при увеличении, достаточном для точной идентификации видов. Этот метод позволяет учитывать не только численный и видовой состав колонии, но и пространственное распределение видов.

Те же методики, что мы применяли в 2019 г., использовали и при обработке данных предыдущих учетов птиц: 13.06.2005 г. - на п-ове Кони; 14.08.2009 г. - на о. Завьялова и 2223.07.2009 г. - в зал. Одян и Речной. Однако в опубликованных данных предыдущих учетов (Зеленская, 2013) не приводилось координат колоний. Единство методик и применение GPS-навигатора позволяет провести сравнение и выявить изменения в численности и в распределении колоний за последнее десятилетие. Поэтому на рисунках и в таблицах показаны распределение и численность птиц в колониях, зафиксированных в предыдущих наших учетах.

\section{РЕЗУЛЬТАТЫ}

Распределение колоний по побережью п-ова Кони представлено на рис. 2, в зал. Речной и Одян - на рис. 3, на о. Завьялова - на рис. 4. Нумерация колоний на каждом участке сквозная (пронумерованы все колонии, зафиксированные в разные годы и закартированные GPS в порядке следования лодки). Численность птиц в колониях приведена в табл. 1, 2 и 3, соответственно. Номера колоний в таблицах соответствуют номерам колоний на рисунках для каждого участка. Это позволяет отследить как исчезновение, так и появление отдельных колоний.

\section{Повидовые изменения в численности}

\section{и распределении морских птиц}

Берингов баклан. Птицы гнездятся небольшими моновидовыми «городками» в колониях, обычно совместно с тихоокеанскими чайками. Общая численность за последнее десятилетие на западном побережье п-ова Кони выросла более чем вдвое (см. табл. 1). Самый значительный рост отмечен на м. Скалистый (северное побережье п-ова Кони) - от единичных гнезд до более чем 200 (№ 6, рис. 2; табл. 1). Почти вдвое возросла численность бакланов на о. Умара (№ 36, рис. 2; табл. 4).

Значительный рост численности беринговых бакланов за последнее десятилетие наблюдается и на о. Завьялова с одновременной экспансией их гнездовий на весь периметр острова (см. табл. 3 ). 
Если в 2009 г. была найдена единственная колония бакланов, состоящая из 11 гнезд (№ 8, рис. 4), то в 2019 г. обнаружено 10 мест гнездования бакланов. При этом на месте бакланьего поселения 2009 г. в настоящее время занятых гнезд нет, остались только гнезда чаек. На западном побережье острова появились мелкие поселения бакланов по 5-6 гнезд (№ 4, 6, рис. 4), большинство колоний найдены на юго-восточном побережье (№ 13-15 и 18-19, рис. 4), они состоят из 3-16 гнезд. На севере острова обнаружены только две колонии бакланов, но именно здесь находится самая крупная из них, в ней были учтены 44 гнезда (№ 28, рис. 4).

В то же время численность бакланов на южном побережье п-ова Кони осталась стабильна, а в материковых колониях от м. Кир до о. КаменьМугдыкын (см. рис. 3) численность снизилась с 1.1 до 0.6 тыс. особей (см. табл. 2). На этом участке побережья среднее число бакланов в колониях в 2009 г. составляло 42 пары, в 2019 г. - 17 пар. Если в 2009 г. были отмечены три колонии, в каждой из которых гнездилось более 100 пар бакланов, то в 2019 г. таких крупных колоний бакланов здесь не было.

Тихоокеанская чайка. Фоновый вид, населяющий все побережье и острова. Гнездятся чайки в основной массе в мелких колониях (по 2080 пар). В последнее десятилетие на материковом побережье наблюдается уменьшение числа гнездящихся пар в колониях и одновременно дробление их колоний на ряд мелких, расположенных рядом, в которые, вероятно, и перемещается часть гнездовой популяции. Крупные колонии деградируют. Так, на п-ове Кони в 2009 г. три колонии содержали более 600 пар, а 2019 г. - только две; более 100 пар содержали раньше 4 колонии, в 2019 г. - три (см. табл. 1). На участке от м. Кир до о. Камень-Мугдыкын в 2009 г. были зафиксированы три колонии численностью более 500 пар каждая, в 2019 г. таких крупных колоний уже не было (см. табл. 2). На этом участке в 2009 г. было отмечено 8 колоний чаек численностью более 150 пар, в 2019 г. колоний таких размеров было 9, из них 5 новые (их не было в 2009 г.), две - выросшие и одна - значительно уменьшившаяся с 2009 г.

Небольшой рост общей численности тихоокеанской чайки в материковых колониях отмечен только на южном побережье п-ова Кони в районе м. Блиган (№ 34-41 и 44, рис. 2) и на северном побережье, на м. Скалистый (№ 6, рис. 2; табл. 1), а также на соседнем о. Умара (№ 36, рис. 3 ; табл. 4).

Значительный рост численности тихоокеанской чайки (в 2.5 раза за последние 10 лет) отмечен на о. Завьялова (см. табл. 3). Рост численности чаек проявляется как в возникновении новых колоний там, где прежде гнезд не было (было найдено 7 новых колоний), так и в увеличении размеров колоний до крупных, численно- стью более сотни гнезд. Так, в 2009 г. на о. Завьялова обнаружены только две крупные колонии, состоящие, в среднем, из 149 гнезд. В 2019 г. крупных колоний обнаружено пять, состоящих, в среднем, из 214 гнезд. Три из них (№ 10, 13 и 31, рис. 2) выросли из небольших (от 2 до 23 гнезд в 2009 г.), а две колонии (№ 22 и 27, рис. 2) десять лет назад не существовали. Именно одна из последних колоний (№ 22, рис. 2) в настоящее время является крупнейшим поселением тихоокеанской чайки на о. Завьялова, состоящим из 414 гнезд.

Обыкновенная моевка. На п-ове Кони моевка сейчас гнездится только на м. Скалистый, и ее численность в этой крупной колонии с 2005 по 2016 г. снизилась. Исчезла маленькая колония между м. Скалистый и м. Плоский (№ 2, рис. 2), где моевки гнездились в 2005 г. (см. табл.1). Однако в зал. Одян наблюдается противоположная картина: на о. Умара (№ 36, рис. 3) численность гнездящихся моевок растет (см. табл. 4), еще стремительнее растет колония моевок на o. Камень-Мугдыкын в бух. Мелководная (№ 35, рис. 3) и появилась новая колония на м. Нерпичий (№ 33, рис. 2; табл. 2). На выходе из зал. Одян на м. Беринга колония моевок переместилась на соседний участок мыса и почти вдвое выросла в численности (№ 22, рис. 3; табл. 2). В зал. Речной моевки гнездятся только около Ольской лагуны (см. рис. 3) и их численность падает. В 2019 г. исчезла колония на м. Харбиз (№ 3, рис. 3), уменьшилась крупная колония моевок на м. Кир (№ 2, рис. 3), сохранилась небольшая колония рядом (№ 1, рис. 3; табл. 2).

Очковый чистик. Численность очкового чистика на материковом побережье и на побережье о. Завьялова стабильно невелика (см. табл. 1, 2). Учеты, как правило, проводили не в период максимальной активности (раннее утро), а в маршрутных поездках, поэтому делать какие-либо выводы об изменениях в их численности не корректно. Единственное гнездовье со стабильно высокой численностью чистиков - о. Умара (см. табл. 4).

Кайры. Гнездование кайр - и тонкоклювой, и толстоклювой - в восточной части Тауйской губы отмечено только на о. Умара и м. Скалистый. Ранее кайры на м. Скалистый в небольшом количестве были отмечены только в 1974 г. (Велижанин, 1978). Никаких кайр на мысе не было уже в 1987 г. (Лейто, Мянд, 1991). Кайры отсутствовали здесь при учетах в 1996 и 2005 г. Первое наблюдение кайр на м. Скалистый после 1974 г. произошло в 2013 г., при регулярном ежегодном обследовании гнезд хищных птиц (Е. Р. Потапов, И. Г. Утехина, устн. сообщ.). Задачи обследования побережья были иными, и наличие кайр было просто зарегистрировано и подтверждено фотографированием фрагмента колонии. Мы учитывали и привели в таблице оба вида кайр вместе, но стоит отметить подавляющее (более 90\%) преобладание тонкоклювой кайры. 


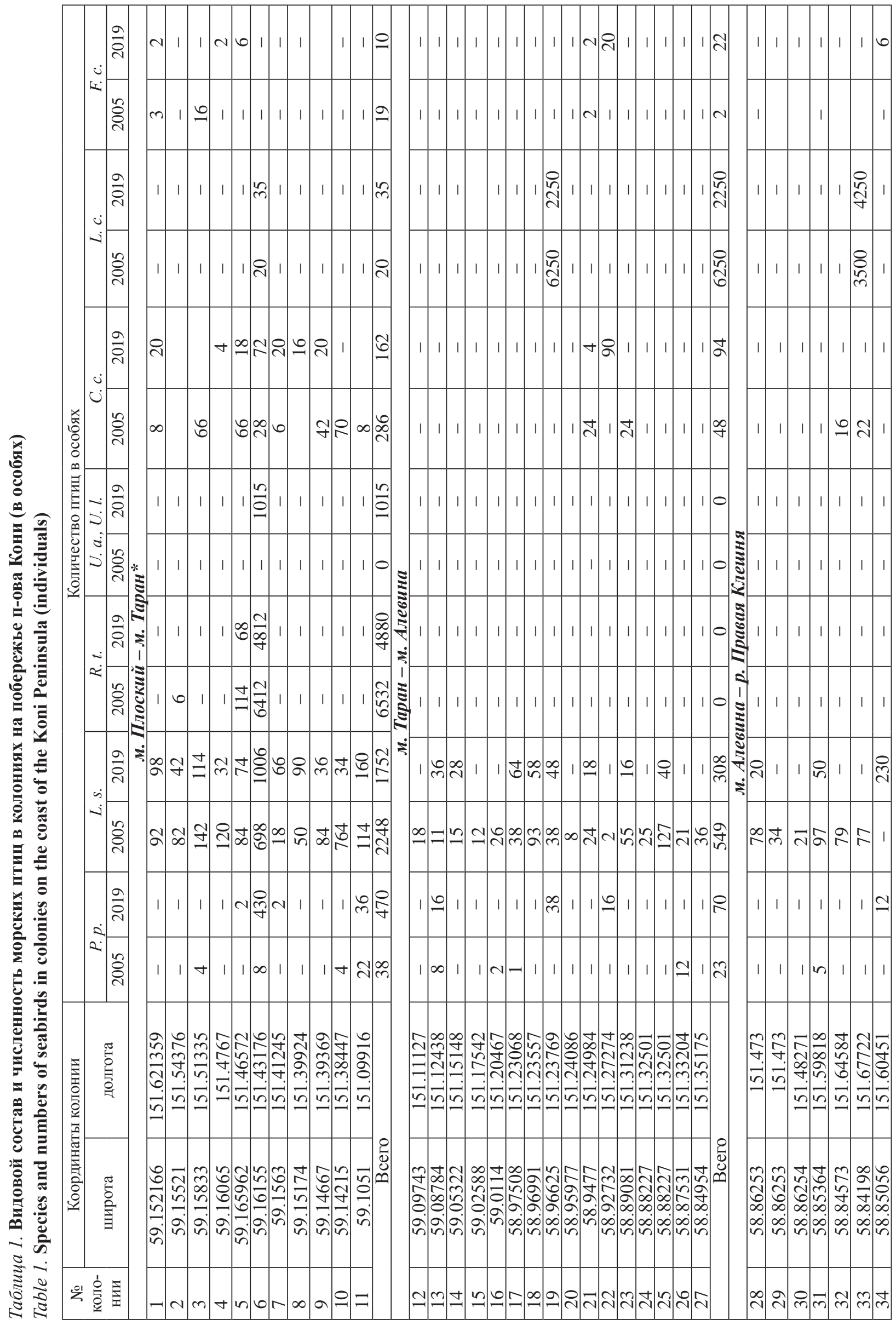




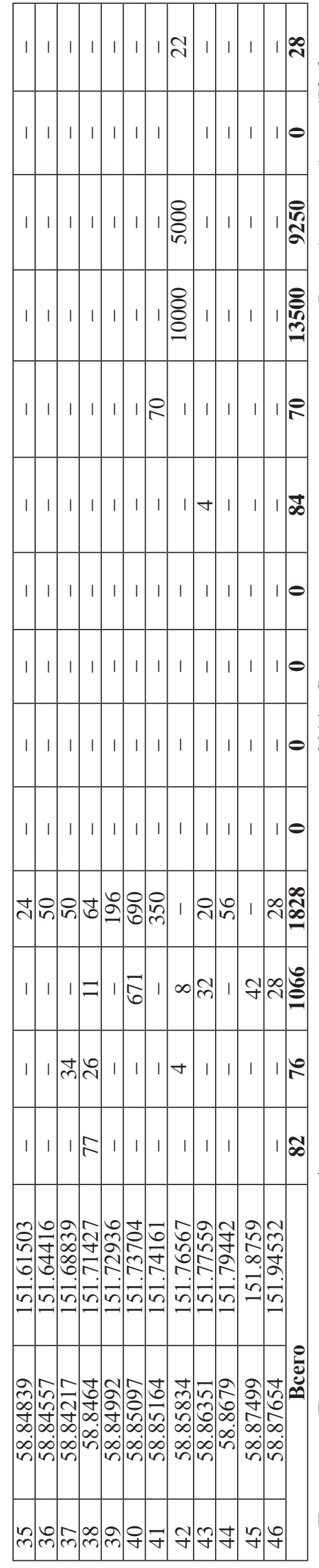

Рост численности кайр в колонии можно считать стремительным. Через три года после первого появления здесь гнездилось более 1 тыс. особей (см. табл. 1). Колония кайр на о. Умара продолжает расти (см. табл. 4).

Топорок. Почти все топорки п-ова Кони гнездятся в трех колониях. На одном кекуре близ м. Первый (колония № 19, рис. 2) и в районе м. Блиган: на кекуре (№ 33, рис. 2) и на задернованном крутом обрыве (№ 42, рис. 2). Это высокие кекуры с вертикальными стенами, которые доступны лишь для визуального поверхностного обозрения, и оценка численности гнездящихся в норах птиц может сильно колебаться. Численность птиц в этих крупных колониях носит скорее оценочный характер, поскольку топорки позднее других видов приступают к гнездованию из-за промороженности почвы и медленного протаивания льда в норах. От погодных условий зависит и обилие топорков на воде рядом с гнездовыми колониями и около нор. Несмотря на то что по учетным данным численность этого вида выглядит сильно колеблющейся (см. табл. 1), вероятнее всего, цифры отражают только сложность учетов в конкретных погодных условиях. Возможно, эти многолетние колонии имеют стабильно высокую общую численность около 10-20 тыс. особей. Колония топорков на о. Умара продолжает быть самой крупной (более 30 тыс. особей) по численности (см. табл. 4) на обследуемой территории (см. табл. 1-3).

В 2019 г. была обнаружена новая колония топорков и тихоокеанских чаек в зал. Речной (№ 8, рис. 3) на береговом обрыве на «балконовидной» террасе, недоступной для лисы. Отмечено начало «кочкования» травянистой растительности в районе концентрации нор топорков, что говорит о том, что поселение стабильно существует уже не один год. Такое преобразование растений вызывается роющей деятельностью топорков (Мочалова и др., 2006).

Ипатка. Численность ипаток на всей обследованной территории остается стабильно низкой (см. табл. 1-4). Ипатки гнездятся только в расщелинах, недоступных для наземных хищников скальных обрывов. Как правило, удобных мест для их гнезд не много.

Белобрюшка. В 2016-2019 гг. подтвердилось окончательное исчезновение вида-планктофага белобрюшки на о. Умара, которую мы учитывали как редкую на гнездовье в 2005 г. и еще наблюдали единичных птиц в 2006 г. (см. табл. 4). Все остальные виды, гнездящиеся в настоящее время как на о. Умара, так и на всей остальной обследованной территории, - ихтиофаги и полифаги.

Региональные изменения в численности и распределении морских птиц

Побережье п-ова Кони. От м. Плоский до устья рр. Правая и Левая Клешня (рис. 2, № 46), 
Таблица 2. Видовой состав и численность морских птиц в колониях на побережье зал. Речной и Одян (в особях)

Table 2. Species and numbers of seabirds in colonies on the coast of the Rechnoy and the Odyan inlets (individuals)

\begin{tabular}{|c|c|c|c|c|c|c|c|c|c|c|c|c|c|c|}
\hline \multirow{2}{*}{$\begin{array}{c}\text { № } \\
\text { коло- } \\
\text { нии }\end{array}$} & \multicolumn{2}{|c|}{ Координаты колонии } & \multicolumn{2}{|c|}{ P. p. } & \multicolumn{2}{|c|}{ L. $s$. } & \multicolumn{2}{|c|}{ R. $t$. } & \multicolumn{2}{|c|}{ C. c. } & \multicolumn{2}{|c|}{ L.c. } & \multicolumn{2}{|c|}{ F.c. } \\
\hline & широта & долгота & 2009 & 2019 & 2009 & 2019 & 2009 & 2019 & 2009 & 2019 & 2009 & 2019 & 2009 & 2019 \\
\hline 1 & 59.53014 & 151.48844 & 262 & 10 & 238 & 48 & 342 & 364 & - & - & - & - & - & - \\
\hline 2 & 59.52025 & 151.49535 & 220 & 188 & 82 & 12 & 2494 & 1742 & - & 2 & - & - & - & - \\
\hline 3 & 59.5052 & 151.51705 & 112 & 26 & 1132 & 126 & 36 & - & 42 & - & - & - & - & - \\
\hline 4 & 59.48443 & 151.61554 & - & 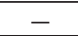 & 50 & - & - & - & - & - & - & - & - & 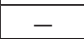 \\
\hline 5 & 59.48048 & 151.62651 & - & - & 22 & - & $\overline{-}$ & - & $\overline{-}$ & - & $\overline{-}$ & - & $\begin{array}{cc}- & \\
\end{array}$ & $\overline{-}$ \\
\hline 6 & 59.46062 & 151.6582 & 38 & - & 74 & - & - & - & - & - & - & - & - & - \\
\hline 7 & 59.42688 & 151.68834 & - & - & 28 & 8 & - & - & - & - & - & - & - & 12 \\
\hline 8 & 59.41496 & 151.69761 & - & $\begin{array}{lll}- \\
-\end{array}$ & - & 250 & - & - & - & - & - & 75 & - & - \\
\hline 9 & 59.47609 & 151.69852 & - & $\begin{array}{ll}- \\
-\end{array}$ & 326 & - & - & - & 140 & $\begin{array}{ll}- \\
-\end{array}$ & - & - & - & - \\
\hline 10 & 59.39429 & 151.6947 & - & 22 & 12 & 52 & $\begin{array}{llll}- & & & \end{array}$ & - & $\begin{array}{lll}- \\
\end{array}$ & $\begin{array}{llll}- & & & \end{array}$ & $\begin{array}{llll}- & & & \end{array}$ & - & - & - \\
\hline 11 & 59.38223 & 151.72048 & - & - & - & 16 & $\begin{array}{ll}- \\
-\end{array}$ & $\begin{array}{ll}- \\
-\end{array}$ & - & $\begin{array}{ll}- \\
-\end{array}$ & - & - & $\begin{array}{ll}- \\
-\end{array}$ & - \\
\hline 12 & 59.37226 & 151.73771 & 34 & 50 & 470 & 82 & $\begin{array}{llll}- & \\
\end{array}$ & $\begin{array}{ll}- \\
-\end{array}$ & 10 & $\begin{array}{llll}- & \\
\end{array}$ & $\begin{array}{ll}- \\
\end{array}$ & - & - & $\begin{array}{ll}- \\
\end{array}$ \\
\hline 13 & 59.36832 & 151.74174 & - & 68 & - & 48 & - & - & - & $\begin{array}{ll}- \\
-\end{array}$ & - & - & - & - \\
\hline 14 & 59.3634 & 151.74834 & - & - & 102 & 28 & $\begin{array}{llll}- & \\
\end{array}$ & - & 16 & 20 & - & - & - & - \\
\hline 15 & 59.35452 & 151.76935 & 286 & - & 670 & 28 & - & - & - & - & - & - & - & - \\
\hline 16 & 59.34811 & 151.76615 & - & - & $\begin{array}{llll}- & & & \end{array}$ & 156 & - & - & $\begin{array}{llll}- & \\
\end{array}$ & - & $\begin{array}{llll}- & \\
\end{array}$ & - & - & - \\
\hline 17 & 59.34269 & 151.76637 & 4 & 12 & - & 338 & - & - & - & - & - & - & - & - \\
\hline 18 & 59.33975 & 151.76473 & - & - & - & 72 & - & - & - & - & - & - & - & - \\
\hline 19 & 59.32591 & 151.71632 & - & 72 & 362 & 146 & - & - & - & 32 & - & $\begin{array}{ll}- \\
-\end{array}$ & - & $\begin{array}{ll}- \\
-\end{array}$ \\
\hline 20 & 59.32156 & 151.72355 & - & - & - & 386 & - & - & - & - & - & - & - & - \\
\hline 21 & 59.30329 & 151.73302 & - & 30 & - & 126 & - & $\begin{array}{ll}- \\
-\end{array}$ & - & - & - & - & - & - \\
\hline 22 & 59.299618 & 151.740697 & - & 6 & 88 & 66 & 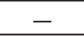 & 132 & 56 & 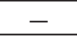 & 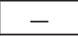 & $\begin{array}{l}- \\
-\end{array}$ & $\begin{array}{llll}- & & & \\
\end{array}$ & $\begin{array}{llll}- & & & \\
\end{array}$ \\
\hline 23 & 59.29858 & 151.7515 & - & 30 & 416 & 294 & 70 & - & - & - & - & - & - & - \\
\hline 24 & 59.29901 & 151.85937 & 2 & 4 & 42 & 36 & 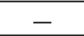 & - & $\begin{array}{ll}- \\
\end{array}$ & $\begin{array}{llll}- & \\
\end{array}$ & $\begin{array}{l}- \\
-\end{array}$ & - & $\begin{array}{llll}- & & & \\
\end{array}$ & 12 \\
\hline 25 & 59.27913 & 151.94298 & 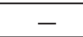 & 20 & 132 & 280 & $\begin{array}{llll}- & & & \\
\end{array}$ & $\begin{array}{l}- \\
\end{array}$ & $\begin{array}{llll}- & & & \\
\end{array}$ & $\begin{array}{ll}- \\
-\end{array}$ & $\begin{array}{lll}- & & \\
\end{array}$ & $\begin{array}{lll}- & & \\
\end{array}$ & $\begin{array}{ll}- \\
-\end{array}$ & 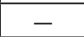 \\
\hline 26 & 59.27187 & 151.96359 & - & 2 & 44 & 46 & - & - & - & - & - & - & - & - \\
\hline 27 & 59.27007 & 151.97723 & 60 & 10 & 138 & 138 & $\begin{array}{llll}- & & & \\
\end{array}$ & $\begin{array}{llll}- & & & \\
\end{array}$ & 6 & $\begin{array}{llll}- & & & \\
\end{array}$ & $\begin{array}{llll}- & & & \end{array}$ & $\begin{array}{lll}- & & \\
\end{array}$ & $\begin{array}{ll}- \\
-\end{array}$ & 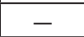 \\
\hline 28 & 59.26338 & 152.00708 & 18 & $\begin{array}{ll}- \\
\end{array}$ & 82 & 130 & $\begin{array}{lllll}- & & & & \\
\end{array}$ & $\begin{array}{llll}- & \\
\end{array}$ & 8 & 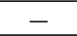 & 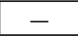 & $\begin{array}{ll}- \\
-\end{array}$ & $\begin{array}{llll}- & & & \\
\end{array}$ & 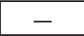 \\
\hline 29 & 59.27499 & 152.03484 & - & 20 & 208 & 60 & $\begin{array}{ll}- \\
\end{array}$ & $\begin{array}{c}- \\
\end{array}$ & 12 & 80 & - & $\begin{array}{ll}- \\
-\end{array}$ & - & $\begin{array}{c}- \\
\end{array}$ \\
\hline 30 & 59.27332 & 152.0469 & - & - & 190 & 46 & - & - & 18 & 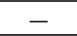 & - & - & - & - \\
\hline 31 & 59.27296 & 152.05191 & - & - & 64 & 50 & - & - & 32 & - & - & - & - & - \\
\hline 32 & 59.27534 & 152.07095 & 50 & - & 158 & 44 & 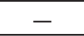 & 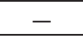 & 50 & 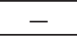 & - & - & - & - \\
\hline 33 & 59.2834 & 152.1416 & 12 & - & 1116 & 428 & - & 20 & 28 & 62 & - & - & 4 & - \\
\hline 34 & 59.28194 & 152.15333 & - & 12 & - & 392 & - & - & - & - & - & - & - & - \\
\hline 35 & 59.26022 & 152.2207 & 2 & 42 & 232 & 352 & 10 & 420 & - & $\begin{array}{llll}- & & & \end{array}$ & $\begin{array}{llll}- & & & \end{array}$ & $\begin{array}{llll}- & & & \end{array}$ & - & $\begin{array}{lll}- \\
\end{array}$ \\
\hline & Bc & & 1100 & 624 & 6478 & 4284 & 2952 & 2678 & 418 & 196 & 0 & 75 & 4 & 24 \\
\hline
\end{tabular}

Примечание. Тире - птицы отсутствуют. Сокращенные названия видов морских птиц см. в табл.1.

по последним учетам в 2016-2019 гг. было обнаружено 35 смешанных и моновидовых колоний морских птиц (см. рис. 2, табл. 1). Мы наблюдаем постепенное уменьшение числа колоний на западном побережье (15 колоний в 2005 г. и 9 - в 2019 г.), стабильную картину на северном побережье (11 колоний) и некоторый рост числа колоний на южном побережье полуострова (13 и 15 колоний соответственно).

Общая численность морских птиц в колониях п-ова Кони снизилась с 30.6 тыс. особей в 2005 г. до 22.1 тыс. особей в 2019 г. Уменьшение количества колоний на западном побережье п-ова Кони и численности птиц в большинстве из оставшихся одновременно сопровождается увеличением численности птиц на колониях м. Скалистый и появлением новых колоний в районе м. Блиган (см. рис. 2). Именно в районах этих мысов, по последним учетам, сосредоточена основная масса гнездящихся морских птиц п-ова Кони: в районе м. Скалистый - 7.5 тыс. особей, в районе м. Блиган - 11.1 тыс. особей.
Колония о. Умара (рис. 2, № 36) самая крупная в восточной части Тауйской губы как по численности, так и по видовому составу. В период 1995-2005 гг. здесь было отмечено общее увеличение численности птиц более чем вдвое (Зеленская, 2006). При этом колония была вполне благополучна в плане обеспеченности кормами, что проявлялось в успешном подъеме птенцов на крыло. Для большинства видов отмечалось расширение области гнездования на острове, вплоть до занятия непривычных биотопов (например, у кайр), а экспансия «клубов» тихоокеанской чайки на свободное пространство уже начала разрушать растительный покров на свободном от гнезд птиц вершинном плато (Там же).

Говорить об относительной стабильности колонии о. Умара можно было бы, сравнивая 2005 и 2016 г., но этому противоречат результаты учета 2006 г., когда было отмечено заметное падение численности (см. табл. 4). Учеты 2005 и 2006 г., проводимые нами по одной методике и почти в одно и то же время как сезона, так и суток, пока- 
Таблица 3. Видовой состав и численность морских птиц в колониях на побережье о. Завьялова (в особях)

Table 3. Species and numbers of seabirds in colonies on the coast of Zavyalov Island (individuals)

\begin{tabular}{|c|c|c|c|c|c|c|c|c|c|c|c|c|}
\hline \multirow{2}{*}{$\begin{array}{l}\text { № ко- } \\
\text { лонии }\end{array}$} & \multicolumn{2}{|c|}{ Координаты колонии } & \multicolumn{2}{|c|}{ P. p. } & \multicolumn{2}{|c|}{ L. $s$. } & \multicolumn{2}{|c|}{ C. $c$. } & \multicolumn{2}{|c|}{ L. C. } & \multicolumn{2}{|c|}{ F.. . } \\
\hline & широта & долгота & 2009 & 2019 & 2009 & 2019 & 2009 & 2019 & 2009 & 2019 & 2009 & 2019 \\
\hline 2 & 59.090398 & 150.610704 & - & $\overline{-}$ & - & 30 & - & - & - & - & - & $\overline{-}$ \\
\hline 3 & 59.082641 & 150.594862 & $\begin{array}{ll}- \\
-\end{array}$ & - & - & 98 & - & - & $\begin{array}{ll}- \\
-\end{array}$ & - & $\begin{array}{ll}- \\
-\end{array}$ & - \\
\hline 4 & 59.081553 & 150.590322 & $\begin{array}{c}- \\
-\end{array}$ & 10 & - & 40 & $\begin{array}{llll}- & \\
\end{array}$ & 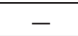 & $\begin{array}{c}- \\
-\end{array}$ & $\begin{array}{c}- \\
-\end{array}$ & $\begin{array}{cc}- \\
-\end{array}$ & 6 \\
\hline 5 & 59.079577 & 150.586075 & - & $\begin{array}{ll}- \\
\end{array}$ & 6 & 64 & - & - & - & 10 & - & - \\
\hline 6 & 59.055707 & 150.523574 & - & 12 & 52 & 96 & - & - & - & - & - & 16 \\
\hline 7 & 59.053345 & 150.521013 & - & 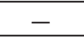 & - & 22 & - & - & - & - & - & - \\
\hline 8 & 59.041787 & 150.500876 & 22 & - & 90 & 62 & - & - & - & - & - & - \\
\hline 9 & 59.000041 & 150.468472 & - & - & 76 & 58 & 52 & - & $\begin{array}{l}- \\
\end{array}$ & - & $\begin{array}{llll}- & & & \\
\end{array}$ & - \\
\hline 10 & 58.999139 & 150.47619 & $\begin{array}{llll}- & & & \\
\end{array}$ & $\begin{array}{llll}- & & & \\
\end{array}$ & 4 & 400 & 214 & $\begin{array}{llll}- & & & \\
\end{array}$ & $\begin{array}{llll}- & & & \\
\end{array}$ & $\begin{array}{l}- \\
-\end{array}$ & $\begin{array}{ll}- \\
-\end{array}$ & $\begin{array}{llll}- & & & \\
\end{array}$ \\
\hline 11 & 58.998077 & 150.493015 & $\begin{array}{llll}- & \\
\end{array}$ & - & 50 & 66 & 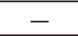 & - & 20 & $\begin{array}{l}- \\
-\end{array}$ & $\begin{array}{l}- \\
-\end{array}$ & $\begin{array}{ll}- \\
-\end{array}$ \\
\hline 12 & 58.997983 & 150.528222 & - & 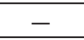 & - & 160 & $\begin{array}{l}- \\
-\end{array}$ & 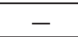 & $\begin{array}{llll}- & & & \\
\end{array}$ & $\begin{array}{llll}- & & & \\
\end{array}$ & 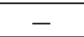 & - \\
\hline 13 & 58.998205 & 150.53934 & $\begin{array}{l}- \\
\end{array}$ & 32 & - & 340 & 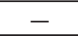 & $\begin{array}{llll}- & & & \\
\end{array}$ & $\begin{array}{l}- \\
\end{array}$ & $\begin{array}{llll}- & & & \\
\end{array}$ & $\begin{array}{llll}- & & & \\
\end{array}$ & - \\
\hline 14 & 58.997029 & \begin{tabular}{|l|}
150.549975 \\
\end{tabular} & $\begin{array}{llll}- & & & \\
\end{array}$ & 6 & 46 & 14 & $\begin{array}{lll}- & & \\
\end{array}$ & $\begin{array}{lll}- & & \\
\end{array}$ & $\begin{array}{llll}- & & & \\
\end{array}$ & $\begin{array}{llll}- & & & \\
\end{array}$ & 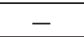 & 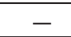 \\
\hline 15 & 58.998394 & 150.568241 & 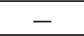 & 8 & 72 & 86 & $\begin{array}{llll}- & & & \\
\end{array}$ & 50 & 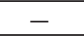 & $\begin{array}{llll}- & & & \\
\end{array}$ & $\begin{array}{llll}- & \\
\end{array}$ & $\begin{array}{llll}- & \\
\end{array}$ \\
\hline 16 & 58.99872 & 150.5734 & - & - & 270 & 12 & 4 & 2 & 15 & - & - & 2 \\
\hline 17 & 59.000375 & 150.58106 & $\begin{array}{llll}- & \\
\end{array}$ & $\begin{array}{llll}- & \\
\end{array}$ & 66 & 154 & $\begin{array}{llll}- & \\
\end{array}$ & 30 & $\begin{array}{llll}- & \\
\end{array}$ & $\begin{array}{llll}- & \\
\end{array}$ & 10 & $\begin{array}{llll}- & \\
\end{array}$ \\
\hline 18 & 59.001596 & 150.58862 & $\begin{array}{lll}- \\
-\end{array}$ & 10 & 32 & 138 & - & $\begin{array}{lll}- & \\
\end{array}$ & $\begin{array}{lll}- \\
-\end{array}$ & $\begin{array}{lll}- & \\
\end{array}$ & $\begin{array}{lll}- & \\
\end{array}$ & - \\
\hline 19 & 59.008334 & 150.613527 & - & 22 & 58 & 74 & - & $\begin{array}{lll}- \\
-\end{array}$ & - & - & - & 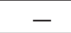 \\
\hline 20 & 59.01502 & 150.63024 & - & - & 86 & 102 & 6 & $\begin{array}{lll}- \\
-\end{array}$ & - & 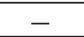 & $\begin{array}{lll}- \\
-\end{array}$ & - \\
\hline 21 & 59.017954 & 150.636218 & - & 4 & 22 & 62 & - & - & - & - & - & - \\
\hline 22 & 59.020949 & 150.643092 & - & - & - & 828 & - & - & - & 20 & - & 6 \\
\hline 23 & 59.029116 & 150.65741 & - & - & 14 & 34 & - & - & - & - & - & - \\
\hline 24 & 59.036888 & 150.668545 & 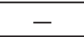 & $\begin{array}{l}- \\
\end{array}$ & 108 & 138 & $\begin{array}{l}- \\
\end{array}$ & $\begin{array}{llll}- & & & 0\end{array}$ & 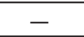 & $\begin{array}{l}- \\
\end{array}$ & $\begin{array}{llll}- & & & 0\end{array}$ & 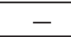 \\
\hline 25 & 59.041435 & 150.67826 & - & - & 32 & 6 & - & - & 30 & - & - & - \\
\hline 26 & 59.077862 & 150.739717 & - & - & 326 & 332 & - & - & - & - & - & - \\
\hline 27 & 59.083241 & \begin{tabular}{|l|}
150.755046 \\
\end{tabular} & 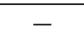 & $\begin{array}{ll}- \\
-\end{array}$ & - & 48 & - & $\begin{array}{lll}- & & \\
\end{array}$ & 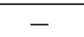 & - & $\begin{array}{lll}- & & \\
-\end{array}$ & $\begin{array}{c}- \\
-\end{array}$ \\
\hline 28 & 59.115457 & \begin{tabular}{|l|}
150.775121 \\
\end{tabular} & $\begin{array}{llll}- & & & \\
\end{array}$ & 88 & 10 & 112 & 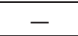 & 34 & 35 & $\begin{array}{l}- \\
-\end{array}$ & 30 & 20 \\
\hline 29 & 59.124158 & \begin{tabular}{|l|}
150.754691 \\
\end{tabular} & - & 20 & - & 128 & - & - & - & - & 18 & - \\
\hline 30 & 59.135819 & 150.689122 & - & - & 132 & 244 & - & - & - & - & - & - \\
\hline 31 & 59.118273 & 150.683014 & - & - & 58 & 88 & 22 & - & 95 & - & - & - \\
\hline 32 & 59.104618 & 150.675331 & - & - & - & 96 & - & $\begin{array}{llll}- & \\
\end{array}$ & - & $\begin{array}{llll}- & & & \\
-\end{array}$ & $\begin{array}{llll}- & \\
\end{array}$ & $\begin{array}{llll}- & \\
\end{array}$ \\
\hline
\end{tabular}

Примечание. Тире - птицы отсутствуют. Сокращенные названия видов см. в табл.1.

зали снижение численности гнездящихся птиц, в основном - бакланов и моевок, для объяснения которого нет данных. В то же время численность кайр и чистиков возросла, а тихоокеанских чаек оставалась стабильной (см. табл. 4). Различия в численности топорков можно объяснить несовершенством методики. Общая численность гнездящихся на о. Умара морских птиц в 2016 г. составляла, по нашим расчетам, около 60.2 тыс. птиц. Колония топорков на о. Умара остается второй по численности в Тауйской губе после о. Талан.
Заливы Речной и Одян. За последние 10 лет исчезли 4 колонии на побережье от м. Кир до м. Речной (см. рис. 3). Имея точные привязки по GPS-координатам, мы можем утверждать, что от м. Речной (№ 9, рис. 3) и до м. Нерпичий (№ 33, рис. 3) число колоний за последние 10 лет выросло. Однако общая численность гнездящихся птиц снизилась в обоих заливах (см. табл. 3). Во многих крупных колониях наблюдается уменьшение числа гнездящихся пар у фоновых видов - тихоокеанской чайки и берингова баклана (см. табл. 2) и одновременно

Таблица 4. Видовой состав и численность морских птиц на о. Умара (в особях) по учетам разных лет Table 4. Species and numbers of seabirds in colonies on Umara Island (individuals) in different years

\begin{tabular}{|c|c|c|c|c|c|c|c|}
\hline \multirow{2}{*}{ Виды птиц } & \multicolumn{7}{|c|}{ Дата учетов } \\
\hline & $1974 *$ & $1987 * *$ & $1992 * * *$ & $1995 * * * *$ & $13.06 .2005 * * * * *$ & 07.06 .2006 & 19.06 .2016 \\
\hline Берингов баклан & 500 & 1374 & 2000 & 344 & 752 & 342 & 612 \\
\hline $\begin{array}{l}\text { Тихоокеанская } \\
\text { чайка }\end{array}$ & 2000 & 2260 & 2000 & 2078 & 5964 & 5844 & 6130 \\
\hline $\begin{array}{l}\text { Обыкновенная } \\
\text { моевка }\end{array}$ & 3000 & 4170 & 3000 & 3178 & 13996 & 9090 & 12418 \\
\hline Очковый чистик & Десятки & 458 & 400 & 614 & 1272 & 1734 & 1020 \\
\hline Топорок & 6000 & 2420 & $>1000$ & 5000 & 35610 & 30800 & 30000 \\
\hline Ипатка & Десятки & - & 30 & 50 & 46 & 10 & 8 \\
\hline Кайры, оба вида & Десятки & 400 & 106 & 950 & 3929 & 6236 & 10000 \\
\hline Белобрюшка & - & - & 107 & 194 & 17 & 7 & - \\
\hline Всего & $>11600$ & 11082 & 8643 & 12408 & 61585 & 54063 & 60188 \\
\hline
\end{tabular}

*Велижанин, 1977; **Лейто, Мянд, 1981; ***Голубова, Плещенко, 1997; ****Зеленская, 1995; *****Зеленская, 2013. 
отмечается дробление их колоний на ряд мелких, расположенных рядом (см. рис. 3). Численность гнездящихся морских птиц в зал. Речной и Одян снизилась с 10.9 тыс. особей в 2009 г. до 7.9 тыс. особей в 2019 г.

Остров Завьялова. В последнее десятилетие продолжается рост числа колоний морских птиц на о. Завьялова в основном благодаря увеличению численности фоновых гнездящихся видов тихоокеанских чаек и беринговых бакланов (см. табл. $3 ; 5)$. В то же время численность немногочисленных очковых чистиков и топорков продолжает здесь падать (см. табл. 5).

Таблица 5. Численность (в особях) морских птиц о. Завьялова по учетам разных лет

Table 5. Numbers (individuals) of seabirds on Zavylov Island in different years

\begin{tabular}{|l|c|c|c|}
\hline \multicolumn{1}{|c|}{ Виды птиц } & \multicolumn{3}{|c|}{ Дата учетов } \\
\cline { 2 - 4 } & $1991^{*}$ & $14.08 .2009^{* *}$ & $7.07 .2019^{* *}$ \\
\hline $\begin{array}{l}\text { Берингов } \\
\text { баклан }\end{array}$ & 70 & 22 & 212 \\
\hline $\begin{array}{l}\text { Тихоокеанская } \\
\text { чайка }\end{array}$ & 1578 & 1626 & 4132 \\
\hline $\begin{array}{l}\text { Очковый } \\
\text { чистик }\end{array}$ & 756 & 298 & 116 \\
\hline Топорок & 424 & 195 & 30 \\
\hline Ипатка & 23 & 58 & 50 \\
\hline \multicolumn{1}{|r|}{ Всего } & $\mathbf{2 8 5 1}$ & $\mathbf{2 1 8 3}$ & $\mathbf{4 5 4 0}$ \\
\hline
\end{tabular}

*Голубова, Плещенко, 1997. **Наши данные.

\section{ОБСУЖДЕНИЕ}

Фоновый вид, представленный почти во всех колониях морских птиц в исследуемом районе, тихоокеанская чайка. Имея точные привязки по GPS-координатам, мы можем утверждать, что одновременно с деградацией и исчезновением некоторых колоний появляются новые колонии. При этом в последние 15 лет общая численность тихоокеанской чайки на п-ове Кони оставалась стабильной (см. табл. 1). Возможно, происходит переселение этого вида. Поскольку заповедный п-ов Кони и труднодоступный о. Завьялова - районы, практически не затрагиваемые деятельностью человека, то антропогенный фактор воздействия на колонии здесь мы можем не рассматривать.

Зона максимальной плотности (\% вероятности обнаружения) мезопланктона в восточной части Тауйской губы находится в районе м. Скалистый (Афанасьев и др., 1994). К районам с высокой концентрацией мезопланктона приурочены основные концентрации мальков и личинок рыб. Таким образом, м. Скалистый, а также м. Блиган и о. Завьялова, попадающие под непосредственное воздействие Ямского холодного течения (см. рис. 1), имеют наиболее богатую кормовую базу для поддержки колоний морских птиц. Именно на м. Скалистый расположены крупнейшие на полуострове колонии морских птиц, при этом рост численности морских птиц здесь продолжается. Аналогичный район концентрации колоний морских птиц-ихтиофагов находится на южном побережье п-ова Кони - в районе м. Блиган.

К сожалению, в последней сводке, обобщающей фундаментальные и прикладные работы, посвященные особенностям среды и ресурсам Тауйской губы (Ландшафты..., 2006), приведены данные морских исследований только по 2003 г. О более поздних изменениях в состоянии моря мы можем судить лишь по косвенным данным. Планктонные съемки в Тауйской губе в последние годы не проводились.

При столь высокой продуктивности морских вод возникает вопрос: почему на м. Скалистый рост численности тихоокеанской чайки за последнее десятилетие не очень высок? На наш взгляд, это может объясняться, во-первых, стабильностью условий для размещения гнезд чаек (насыщение скальных обрывов, недоступных для наземных хищников). Сдерживать рост численности гнездящихся на склонах тихоокеанских чаек могут мелкие хищники, а также бурый медведь, численность которого на п-ове Кони высока. Во время учетов мы наблюдали двух взрослых животных, осматривающих склоны на вершине м. Скалистый.

Во-вторых, сдерживать рост численности чаек может стабильность/ограниченность естественной кормовой базы чаек. В районе м. Скалистый относительно большие глубины и отсутствует зона литоральной осушки, где обычно тихоокеанская чайка добывает корм.

Вероятно, именно хорошая кормовая база для глубоко ныряющих чистиковых птиц, обусловленная циркуляцией вод в Тауйской губе (см. рис. 1), способствовала восстановлению колонии кайр на м. Скалистый после почти 40-летнего перерыва. Возможно, некоторое снижение численности моевки за последние десять лет на м. Скалистый также связано с восстановлением колонии кайр. По нашему мнению, снижение численности моевок может, в какой-то мере, являться результатом конкуренции с кайрами за обладание гнездовыми карнизами (оба вида имеют сходные требования к скальным выступам, но моевка меньше размерами). Мы наблюдали аналогичную картину на о-вах Три Брата (бух. Гертнера, Тауйская губа). Все узкие скальные полки там, как и на м. Скалистый, были плотно заняты птицами. Недостаток места приводил к тому, что кайры плотно стояли на краях гнезд инкубирующих моевок и между ними, активно сопротивляясь попыткам прогнать их. Такая конфронтация моевок и кайр описывалась и ранее на Мурмане (Белопольский, 1957). Возможно, не выдержав конкуренции с кайрами, часть моевок переместилась на гнездовые колонии о. Умара в зал. Одян, где численность гнездящихся моевок возросла.

Следующее изменение на м. Скалистый - значительный рост численности беринговых бакланов с 2005 г. За десятилетие до учетов 2005 г. гнез- 
да бакланов на мысе были также немногочисленными (Голубова, Плещенко, 1997). С одной стороны, возрастание численности от единичных гнезд до более чем 200 могло бы говорить об изменениях в акватории вокруг мыса (изменения в кормовой базе), с другой - беринговы бакланы склонны периодически резко менять места гнездования, просто покидая старые колонии на много лет и заселяя новые скалы. Предполагается, что это служит защитой от гнездовых паразитов, хорошо перезимовывающих в их гнездовых постройках (Мараков, 1972). Возможно, мы наблюдаем именно такой случай. То, что м. Скалистый может поддерживать такую высокую численность гнезд бакланов, свидетельствует о богатой кормовой базе (молоди и мелких видов придонных рыб).

Окончательное исчезновение планктофага белобрюшки в колонии о. Умара, по нашему мнению, является закономерным продолжением изменения распределения зоопланктона из-за климатических изменений в акватории Тауйской губы. На о. Талан в западной части Тауйской губы расположена одна из крупнейших в Охотском море колоний морских птиц (более 1 млн особей, по: Кондратьев и др., 1992). По учетам 20072008 гг. за последние 20 лет численность морских птиц здесь снизилась на 50\% (Андреев и др., 2010). Климатические изменения вызывают резкое снижение численности морских птиц на о. Талан, что давно вызывало и продолжает вызывать тревогу и озабоченность исследователей (Андреев, 2002, 2004; Андреев, Голубова, 2019). В основном этот процесс коснулся самых массовых на этом острове планктоноядных видов морских птиц: большой конюги (Aethia cristatella), старика (Synthliboramphus antiquus), белобрюшки. Из ихтиофагов снижение численности отмечено у топорка, а численность ипатки и моевки, наоборот, возросла. Численность кайр (ихтиофагов) осталась примерно на прежнем уровне (Андреев и др., 2010).

Кормовая база о. Завьялова, судя по быстрому росту числа гнезд тихоокеанской чайки и берингова баклана (см. табл. 5), успешно поддерживает их численность. Вероятно, этому способствует непосредственное воздействие Ямского течения на акваторию (см. рис. 1). Но рост численности тихоокеанской чайки в колониях о. Завьялова не столь стремителен, как, например, на барах Ольской лагуны (Хорева и др., 2016). Сдерживающим фактором, при отсутствии антропогенного пресса, по нашему мнению, является хищничество. На о. Завьялова на недоступных для наземных хищников участках скал главной опасностью для гнездящейся тихоокеанской чайки, по нашим наблюдениям, является хищничество белоплечего орлана. Только при приближении орлана мы наблюдаем панические взлеты всех тихоокеанских чаек в колонии, служащие коллективной защитой гнездовья. Даже на бродящего по колонии че- ловека или бурого медведя реакция чаек намного слабее - взлетают только птицы, находящиеся неподалеку от опасности. Тихоокеанская чайка и ее птенцы являются обычной добычей белоплечего орлана в районе Тауйской губы. Мы неоднократно наблюдали поедание орланом взрослых чаек на скальных обрывах. Остатки характерно расклеванных тушек как взрослых чаек, так и подрастающих птенцов мы обнаруживали и на колониях чаек, и в гнездах орланов.

Вырисовывается возможная прямая взаимосвязь численности колоний тихоокеанских чаек с наличием/исчезновением гнездящейся пары белоплечих орланов, что особенно хорошо видно в островной экосистеме. Так, на участках № 27 и 31 (см. рис. 4), где в настоящее время исчезли пары орланов, которые гнездились в 2009 г., появились или значительно выросли колонии тихоокеанских чаек (табл. 6). Падение численности гнездящихся чаек на участках № 16, 25 и 8 (см. рис. 4), возможно, также связано с появлением нового гнезда орланов и продолжением существования старого (табл. 6). Объяснима и ситуация на участке № 5 (см. табл. 3), где наблюдается продолжающаяся деградация плотной колонии топорков на изолированном от хищных млекопитающих кекуре. Чайки заселяют вершину кекура, вытесняя топорков, а орланы, вероятно, продолжают охотиться на менее маневренных топорков. Недостаток информации не дает возможности интерпретировать ситуацию на участке № 7, где за последнее десятилетие появились и гнездо орлана, и небольшая колония чаек (табл. 3,6 ).

Другая ситуация в зал. Одян и Речной, а также и о. Умара, которые подвержены антропогенному прессу, выражающемуся в регулярных посещениях людьми. Временные базы рыбаков можно найти на всем протяжении этого побережья. Северная часть зал. Одян, изрезанная заливами, традиционно является зоной браконьерского лова лососей и крабов.

Остров Умара не входит в состав заповедника «Магаданский», но его удаленное расположение

Таблица 6. Соотношение числа гнезд тихоокеанской чайки и белоплечего орлана в разных колониях на побережье о. Завьялова в разные годы

Table 6. Ratio of the Slaty-backed Gull and the Steller's Sea Eagle nests in different colonies on the coast of Zavyalov Island in different years

\begin{tabular}{|l|c|c|c|c|}
\hline \multirow{2}{*}{ № колонии } & \multicolumn{4}{|c|}{ Количество гнезд } \\
\cline { 2 - 5 } & \multicolumn{2}{|c|}{2009 г. } & \multicolumn{2}{|c|}{2019 г. } \\
\cline { 2 - 5 } & Чайки & Орланы & Чайки & Орланы \\
\hline 5 & 3 & 1 & 32 & 1 \\
\hline 7 & 0 & 0 & 11 & 1 \\
\hline 8 & 45 & 1 & 31 & 1 \\
\hline 16 & 135 & 0 & 6 & 1 \\
\hline 25 & 16 & 0 & 3 & 1 \\
\hline 27 & 0 & 1 & 166 & 0 \\
\hline 31 & 29 & 1 & 122 & 0 \\
\hline
\end{tabular}


(до ближайшего поселка 90 км) значительно снижает антропогенный пресс. Периодический сбор яиц тихоокеанской чайки рыбаками с проходящих катеров происходит не каждый год и по масштабам носит относительно умеренный характер. Однако частое посещение острова людьми привело к тому, что с 2006 г. больше не гнездится белоплечий орлан, до того ежегодно поднимавший 1-2 птенцов на крыло. В настоящее время свободной от гнезд морских птиц остается лишь часть вершинного плато острова. Но и здесь отмечены «проплешины» в травянистом растительном покрове, вызванные «клубной» активностью тихоокеанской чайки. Численность тихоокеанской чайки на о. Умара в последнем десятилетии относительно стабильна (см. табл. 4). Возможно, это связано с легкой доступностью пологих участков вершины острова для людей, собирающих яйца чаек.

Исчезновение колоний морских птиц на побережье от м. Кир до м. Речной, а также снижение численности моевок в колонии на м. Харбиз связаны, вероятно, с заметным оживлением в последние годы активности рыбаков, круглогодично курсирующих из Ольской лагуны и обратно. Численность морских птиц может сокращаться не только из-за регулярного присутствия людей, но и из-за прямого уничтожения птиц для наживки в краболовках. При удалении от Ольской лагуны (южнее м. Речной) наблюдается противоположная картина - число колоний растет (см. табл. 2).

Снижение численности тихоокеанской чайки на побережье зал. Одян и Речной можно связать не только с антропогенным прессом. Возможно, это следствие естественного разрушения скал на открытых для штормов мысах. Вероятно, стремительный рост численности чаек на островных барах Ольской лагуны (Хорева и др., 2016) связан с активным переселением чаек с побережья зал. Одян и Речной.

\section{ЗАКЛЮЧЕНИЕ}

Численность морских птиц. Всего по последним учетам в восточной части Тауйской губы: на заповедном побережье п-ова Кони, в зал.Одян и Речной и на о. Завьялова гнездится более 92 тыс. морских птиц. Их основная масса гнездится на о. Умара - 60.2 тыс. особей, в районе м. Блиган (п-ов Кони) - 11.1 тыс. особей и в районе м. Скалистый (п-ов Кони) - 7.5 тыс. особей. На всем побережье зал. Одян и Речной гнездится 7.9 тыс. особей, на о. Завьялова - 4.5 тыс. особей.

Видовой состав. В исследованном районе гнездится 8 видов морских птиц, но основную долю по численности представляют 4 вида (в порядке уменьшения численности): топорок (41.6 тыс. особей), моевка (20.0 тыс. особей), тихоокеанская чайка (18.4 тыс. особей) и тонкоклювая кайра (11 тыс. особей). Львиная доля числа этих видов гнездится на о. Умара (см. табл. 4). За последнее десятилетие исчез из числа гнездящихся на острове видов редкий планктофаг - белобрюшка. Остаются редкими на гнездовье ипатка и толстоклювая кайра. Несмотря на рост численности в отдельных колониях, продолжают быть немногочисленными на гнездовье берингов баклан и очковый чистик.

Распределение видов и основные изменения за последнее десятилетие. Тихоокеанская чайка, берингов баклан и очковый чистик относительно равномерно распределены на всех недоступных для хищников скалах вдоль побережья со значительными концентрациями гнезд на о. Умара и м. Скалистый. Численность гнезд беринговых бакланов на м. Кир снизилась, а на о. Завьялова выросла, и их гнезда распространены сейчас вдоль всего побережья. Численность гнездящихся тихоокеанских чаек снижается (за исключением колоний о-вов Умара, Завьялова и м. Скалистый), возможно, происходит перемещение гнездящихся птиц в Ольскую лагуну.

Гнездовья топорков сосредоточены на о. Умаpa, двух кекурах около м. Блиган и на кекуре у м. Первый. Кайры, помимо основной растущей колонии на о. Умара, восстановили колонию на м. Скалистый. Гнездовья моевок, помимо о. Умара и м. Скалистый, сосредоточены в колониях у м. Кир, растут их колонии на о. Камень-Мугдыкын и м. Нерпичий и Беринга.

За период с 2009 по 2019 г. на восточном побережье Тауйской губы от м. Кир до м. Беринга численность гнездящихся морских птиц снизилась почти на треть. На наиболее часто посещаемом, расположенном ближе к пос. Ола участке побережья некоторые колонии исчезли и одновременно произошло дробление оставшихся колоний на более мелкие, находящиеся неподалеку. На участке побережья от м. Беринга до берега бух. Мелководная состояние колоний морских птиц относительно стабильно, в некоторых колониях наблюдается рост численности гнездовой популяции.

\section{БЛАГОДАРНОСТИ}

Исследования побережья п-ова Кони и колонии на о. Умара проводились в рамках договоров о сотрудничестве и при всемерной поддержке и содействии заповедника «Магаданский». Автор крайне признателен администрации заповедника «Магаданский», госинспекторам заповедника, коллегам и друзьям, принимавшим активное участие в проведении учетов: И. Г. Утехиной, С. А. Швецову, А. И. Котюху (заповедник «Магаданский») за помощь в полевых работах; Е. Р. Потапову (университет Филадельфии, США), без помощи которого учет 2019 г. был бы невозможен.

Экспедиционные исследования о. Завьялова в 2019 г. проходили в рамках программы «Природа острова Завьялова и экологический туризм» и при финансовой поддержке организаторов туристического комплекса «Остров Завьялова». Автор выражает горячее признание коллегам, оказывав- 
шим всемерную поддержку в полевых работах на острове: М. Г. Хоревой, А. А. Примаку, Н. Е. Докучаеву, В. Б. Докучаевой, Е. А. Андрияновой.

\section{ЛИТЕРАТУРА}

Андреев А. В. Колонии морских птиц острова Талан: разрешающая сила постоянства // Природа. 2002. № 10. C. 41-50.

Андреев A. В. Остров Талан: «авианосец» в Тауйских водах // Колыма. 2004. № 1. С. 6-17.

Андреев А. В., Голубова Е. Ю. Многолетняя динамика численности и успеха размножения большой конюги Aethia cristatella Pallas, 1769 на острове Талан (Охотское море) // Вестник ТвГУ. Сер. «Биология и экология». 2019. № 1 (53). С. 15-30.

Андреев А. В., Голубова Е. Ю., Зубакин В. А., Харитонов $C$. П. Численность морских птиц на колониях о. Талан: двадцатилетний тренд // Вестник СВНЦ ДВО РАН. 2010. № 2. С. 30-42.

Афанасьев Н. Н., Михайлов В. И., Чевризов Б. П., Карасёв $A$. $H$. Условия формирования, структура и распределение кормовой базы молоди лососевых рыб в Тауйской губе Охотского моря // Биологические основы развития лососеводства в Магаданском регионе : сб. науч. тр. / ГосНИОРХ, МоТИНРО, Лаборатория рыбоводства Охотскрыбвода. Санкт-Петербург, 1994. С. 25-41.

Белопольский Л.О. Экология морских колониальных птиц Баренцева моря. Москва ; Ленинград : Издво АН СССР, 1957. 435c.

Велижанин А. Г. Новые сведения о морских птицах Дальнего Востока // Зоологический журнал. 1977. Т. 56, № 7. С. 1077-1083.

Велижанин А. Г. Размещение и состояние численности колониальных морских птиц на Дальнем Востоке // Актуальные вопросы природы на Дальнем Востоке. Владивосток : ДВНЦ АН СССР, 1978. С. 154-173.

Голубова Е. Ю. Мониторинг популяций тонкоклювой (Uria aalge) и толстоклювой (Uria lomvia) кайр в Тауйской губе Охотского моря // Зоологический журнал. 2014. Т. 93, № 9. С. 1086-1105.

Голубова Е. Ю., Плещзенко С. В. Колонии морских птиц северной части Охотского моря // Видовое разнообразие и состояние популяций околоводных птиц Северо-Востока Азии. Магадан : СВНЦ ДВО РАН, 1997. C. 141-162.
Зеленская Л. А. Динамика изменений в колонии морских птиц о. Умара (северное Охотоморье) // Биология и охрана птиц Камчатки. Москва : Изд-во Центра охраны дикой природы, 2006. Вып. 7. С. 100-106.

Зеленская Л. А. Колонии морских птиц Тауйской губы и п-ова Кони (Охотское море) // Вестник СВНЦ ДВО РАН. 2013. № 3. С. 87-100.

Зеленская Л. А. Состояние колонии морских птиц о. Умара в 1995 г. // Морские птицы Берингии (инф. бюл.). Магадан : ИБПС ДВО РАН, 1995. С. 46-47.

Кондратьев А. Я., Зубакин В. В., Голубова Е. Ю., Кондратьева Л. Ф., Харитонов С. П., Китайский А. С. Фауна позвоночных животных острова Талан // Прибрежные экосистемы Северного Охотоморья. Остров Талан. Магадан : ИБПС ДВО РАН, 1992. С. 72-109.

Ландшафты, климат и природные ресурсы Тауйской губы Охотского моря. Владивосток : Дальнаука, 2006. 525 c.

Лейто А., Мянд Р. Состав и численность орнитофауны морского побережья // Исследование экосистем полуострова Кони (Магаданский заповедник). Таллин, 1991. С. 166-177.

Мараков С. В. Природа и животный мир Командор. Москва : Наука, 1972. 184 с.

Мочалова О. А., Хорева М. Г., Зеленская Л. А. Растительный покров в колониях топорков Lunda cirrhata на островах Северной Пацифики // Биология и охрана птиц Камчатки. 2006. № 7. С. 107-115.

Нечаев В. А., Гамова Т. В. Птицы Дальнего Востока России (аннотированный каталог). Владивосток : Дальнаука, 2009. 564 с.

Остров Завьялова (геология, геоморфология, история, археология, флора и фауна). Москва : ГЕОС, 2012. $212 \mathrm{c}$.

Хорева М. Г. Флора островов Северной Охотии. Магадан : ИБПС ДВО РАН, 2003. 173 с.

Хорева М. Г., Зеленская Л. А., Андриянова Е. А. Формирование растительного покрова на островных барах Ольской лагуны (Охотское море) в условиях быстрорастущей численности морских птиц // Сибирский экологический журнал. 2016. Т. 23, № 3. С. 299-312.

Чернявский В. И., Радченко Я. Г. Физикогеографическая характеристика Тауйской губы Охотского моря // Биологические основы развития лососеводства в Магаданском регионе : сб. науч. тр. СанктПетербург : ГосНИОРХ, 1994. Вып. 308. С. 10-24.

\title{
CENSUS OF SEABIRD COLONIES OF THE EASTERN PART OF THE TAUY BAY AND OF KONI PENINSULA (Sea of Okhotsk)
}

\section{A. Zelenskaya}

\author{
Institute of Biological Problems of the North, FEB RAS, Magadan
}

The results of the sea bird colonies census in the eastern part on the coast of the Tauy Bay, Zavyalov Island, and the Koni Peninsula are presented and discussed. Recent census allows to assess changes in nesting colonies of seabirds that occurred over the past 10-15 years. Total number of nesting seabirds is estimated as more than 92 thousand individuals. Gradual decrease in the number of seabirds colonies was observed on the west coast of the Koni peninsula. The great bulk of seabirds nesting in here is concentrated around Cape Bligan - 11,1 thousand individuals and on Cape Skalisty - 7.5 thousand individuals. Recovery 
of the colony of murres was recorded. On Cape Skalisty, after almost 30-year absence, and the number of murres quickly grows here. The number of breeding seabirds on Umara Island has remained stable for the last 10 years and is estimated as 60.2 thousand individuals. The total number of breeding seabirds along the surveyed part of the continental coast has decreased from 41.7 thousand individuals to 30.2 thousand in 2009-2019.

\section{Keywords: seabird colony, Sea of Okhotsk, Koni Peninsula, Tauy Bay, Zavyalov Island, number of seabirds, distribution of breeding seabird colonies.}

\section{REFERENCES}

Afanasyev, N. N., Mikhaylov, V. I., Chevrizov B. P., Karasyov, A. N., 1994. Formation Conditions, Structure, and Forage Reserve Distribution of Young Salmon Fishes in the Tauysk Bay of the Sea of Okhotsk, Biological Bases of Salmon Breeding Development in Magadan Oblast, Sbornik Nauchnykh Trudov MO TINRO, St. Petersburg. 25-41 [In Russian].

Andreev, A. V., 2002. Seabird Colonies of Talan Island: Resolving Power of Consistency, Nature. 10, 41-50 [In Russian].

Andreev, A. V., 2004. Talan Island: "Flattop" in the Tauy Waters, Kolyma. 1, 6-17 [In Russian].

Andreev, A. V., Golubova, E. Yu., 2019. Long-Term Dynamics of the Crested Auklet Aethia Cristatella Pallas, 1769 Population and Its Breeding Success on Talan Island (Sea of Okhotsk), Vestnik TvGU. Biology and Ecology. 1 (53), 15-30 [In Russian].

Andreev, A. V., Golubova, E. Yu., Zubakin, V. A., Kharitonov, S. P., 2010. The Number of Sea Birds in the Talan Island Colonies: The 20-year Trend Assessment, Vestnik NESC FEB RAS. 2, 30-42 [In Russian].

Belopolsky, L. O., 1957. Ecology of Colonial Seabirds of the Barents Sea, AS SSSR. Moscow - Leningrad [In Russian].

Chernyavsky, V. I., Radchenko, Ya. G., 1994. Physical and Geographical Characteristics of the Tauysk Bay, Sea of Okhotsk, Biological Basis for of Salmon Breeding Development in Magadan Oblast. St. Petersburg. Iss. 308, 10-24 [In Russian].

Golubova, E. Yu., 2014. Monitoring of the Common Murre (Uria aalge) and Thick-billed Murre (Uria lomvia) Populations in the Tauysk Bay, Sea of Okhotsk, Zoologicheskii Zhurnal. 93, 9, 1086-1105 [In Russian].

Golubova, E. Yu., Pleschenko, S. V., 1997. Seabird Colonies of the North Okhotsk Sea Region, Species Diversity, and Population Status of Waterside Birds in North-East Asia. Magadan, NESC FEB RAS. 141-162 [In Russian].

Khoreva, M. G., 2003. Island Flora of the Northern Okhotia. Magadan, IBPN FEB RAS [In Russian].

Khoreva, M. G., Zelenskaya, L. A., Andriyanova, E. A., 2016. Vegetation Development on the Barrier Islands of the Ola Lagoon (Sea of Okhotsk) under the Rapidly In- creasing Number of Seabirds, Contemporary Problems of Ecology. 9, 3, 254-265.

Kondratyev, A. Ya., Zubakin, V. A., Golubova, E. Yu., Kondratyeva, L. F., Kharitonov, S. P., Kitaysky, A. S., 1992. Vertebrate Fauna of Talan Island, Coastal Ecosystems in the Northern Part of the Sea of Okhotsk, Talan Island. Magadan, IBPN FEB RAS. 72-109 [In Russian].

Landscapes, Climate, and Natural Resources in the Tauysk Bay, Sea of Okhotsk, 2006. Vladivostok, Dalnauka [In Russian].

Leito, A., Mänd, R., 1991. Composition and Density of Ornitofauna on the Seashore, Ecosystem Studies on the Koni Peninsula (Magadan Nature Reserve). Tallinn, 166-177 [In Russian].

Marakov, S. V., 1972. Nature and the Animal World of the Commander Islands. Moscow, Nauka [In Russian].

Mochalova, O. A., Khoreva, M. G., Zelenskaya, L. A., 2006. Vegetation Cover in the Tufted Puffin Lunda cirrhata Colonies on the Islands of the North Pacific, Biology and Conservation of the Birds of Kamchatka. 7, 107-115 [In Russian].

Nechaev, V. A., Gamova, T. V., 2009. Birds of the Russian Far East (Annotated Catalog). Vladivostok, Dalnauka [In Russian].

Velizhanin, A. G., 1977. New Information on Seabirds in the Far East, Zoologicheskii Zhurnal. 56. 7, 1077-1083

[In Russian].

Velizhanin, A. G., 1978. Distribution and Abundance Status of Seabird Colonies in the Far East, Current Problems of Nature Conservation in the Far East. Vladivostok, DVNTS AN SSSR, 154-173 [In Russian].

Zavyalov Island (Geology, Geomorphology, History, Archaeology, Flora, and Fauna), 2012. Moscow, GEOS [In Russian].

Zelenskaya, L. A., 1995. Status of the Seabird Colony on Umara Island, 1995, Beringian Seabird Bulletin. Magadan, IBPN FEB RAS. 3, 44-45.

Zelenskaya, L. A., 2006. Dynamics of the Seabird Colony on the Umara Island, Northern Part of the Sea of Okhotsk, Biology and Conservation of Birds in Kamchatka. Moscow, WWF. Iss. 7, 100-106 [In Russian].

Zelenskaya, L. A., 2013. Seabird Colonies in the Tauysk Bay and on the Koni Peninsula (Sea of Okhotsk), Vestnik NESC FEB RAS. 3, 87-100 [In Russian]. 